\title{
Formation and Assistance of Disaster Resilient Village in Ngargoyoso Village, Ngargoyoso District, Karanganyar Regency, Central Java
}

\author{
Pipit Wijayanti, Rita Noviani, Anton Subarno, Aldi Cahyo Saputro, Anastasia \\ Kintan Nimasari, Aufi Nurma Millati, Febi Monica Karina, Hidayat Fauzi, \\ Muchammad Iqbal Dwidya Muzadi, Muhammad Zaki Zamani, Ryan Erry Atmaji, \\ Sheva Adella Novita, Verido Dwiki Herdhianto
}

Universitas Sebelas Maret

pipitwijayanti@staff.uns.ac.id

\section{Article History \\ accepted 31/08/2020}

\begin{abstract}
The research was carried out in Ngargoyoso Village, Ngargoyoso District, Karanganyar Regency based on the consideration that natural disasters often occur according to landslides. Therefore, an institutional form of Disaster Resilient Village is needed in disaster planning at the village level as a form of increasing disaster preparedness and management. Meanwhile, this research aims to emphasize the village officials, local village youth with the forum Karangtaruna, and the local community. The method of conducting this research is training and mentoring consisting of 6 (six) phases of activities including i) coordination and outreach, ii) FGD (Forum Group Discussion) in a participatory manner by the community, iii) disaster management training, iv) tracing disaster-prone areas, v) assistance in preparing village disaster documents, and vi) evaluating the implementation of activities. The target of the output from the PKM is the formation of the Disaster Resilient Village.
\end{abstract}

Keywords: Village, Resilient, Disaster, Innovation, Community

\section{Abstrak}

Penelitian dilakukan di Desa Ngargoyoso, Kecamatan Ngargoyoso, Kabupaten Karanganyar atas dasar pertimbangan bahwa di daerah tersebut sering terjadi bencana alam tanah longsor. Oleh karena itu, diperlukan suatu bentuk kelembagaan Desa Tangguh Bencana dalam perencanaan kebencanaan di tingkat desa sebagai wujud peningkatan kesiapsiagaan dan penanggulangan bencana. Adapun, sasaran penelitian ini lebih ditekankan terhadap pihak pejabat desa, pemuda desa setempat dengan wadah forum karangtaruna, dan masyarakat setempat. Metode pelaksanaan penelitian ini adalah pelatihan dan pendampingan dengan terdiri dari 6 (enam) tahapan kegiatan meliputi: i) koordinasi dan sosialisasi, ii) FGD (Forum Group Discussion) secara partisipatif oleh masyarakat, iii) pelatihan manajemen kebencanaan, iv) penelusuran wilayah rawan bencana, v) pendampingan penyusunanan dokumen kebencanaan desa, dan vi) evaluasi pelaksanaan kegiatan. Target luaran dari PKM ini adalah terbentuknya Desa Tangguh Bencana.

Kata Kunci: Desa, Tangguh, Bencana, Inovasi, Masyarakat

Social, Humanities, and Education Studies (SHEs): Conference Series

https://jurnal.uns.ac.id/shes 


\section{PENDAHULUAN}

Indonesia merupakan wilayah yang rawan bencana. Hal tersebut dilatarbelakangi suatu realitas bahwa Indonesia dikelilingi tiga lempeng tektonik aktif, deretan gunungapi aktif bagian dari ring of fire dan letak geografis yang dilewati garis khatulistiwa (Pusat Data Informasi dan Humas BNPB. 2019). Dalam hal ini, termasuk pegunungan yang juga memiliki intensitas kerentanan bencana alam. Karena Indonesia telah terkenal dengan pegunungan yang sangat indah dan berapi di dunia, maka kondisi alam yang ada sangat beragam serta dengan adanya keanekaragaman penduduk dan budaya di Indonesia menyebabkan timbulnya resiko terjadinya bencana alam, bencana karena ulah manusia dan kedaruratan kompleks, meskipun disisi lain juga kaya akan sumber daya alam.

Pada umumnya resiko bencana tanah longsor terjadi akibat faktor hydrometeorology. Bencana tanah longsor merupakan salah satu bencana alam yang seringkali terjadi di daerah pegunungan yang disebabkan oleh banyak pemukiman penduduknya ataupun daerahnya berada pada kemiringan yang curam. Selain itu, bencana bisa terjadi karena ulah manusia itu sendiri, Contohnya adalah konflik antar manusia akibat perebutan sumberdaya yang terbatas, alasan ideologi, religius serta politik. Sedangkan kedaruratan bencana tanah longsor yang kompleks merupakan kombinasi dari faktor hydrometeorology dan juga dari manusia itu sendiri sehingga lebih memacu terjadinya bencana tanah longsor.

Berdasarkan Peta Indeks Rawan Bencana Indonesia (2019) yang diterbitkan oleh BNPB, seluruh wilayah Indonesia rawan bencana alam dengan tingkatan kerawanan tinggi, sedang, dan rendah. Peta tersebut menggambarkan sebagian besar wilayah Indonesia memiliki tingkat kerawanan bencana tinggi bencana alam dapat menimpa manusia selain karena faktor alam juga disebabkan oleh faktor lain yaitu faktor sosial, politik, dan ekonomi. Faktor sosial diantaranya manusia karena kondisi ekonomi harus tinggal di daerah rawan bencana misalnya di bantaran sungai, lereng gunung berapi, dan daerah gempa. Untuk menantisipasi keadaan ini masyarakat perlu diberikan pengetahuan dan pendidikan mengenai tangguh bencana, bagaimana metode antisipasi bencana, mencegahnya dan penanganan pasca bencana.

Pengetahuan dan pendidikan cakupannya tidak hanya menciptakan manusia menjadi lebih cerdas dan pintar tetapi juga sebagai perwujudan manusia sebagai mahkluk sosial yang memiliki kepribadian yang baik serta bijaksana. Mahasiswa yang diharapkan sebagai seseorang yang telah menempuh pendidikan tinggi perlu memiliki tiga sifat utama yaitu integritas, etos kerja, dan gotong royong. Untuk pencapaian tiga sifat utama ini maka diperlukan suatu pergerakan sosial yang berdampak bagi masyarakat yang membutuhkan bantuan, khususnya dalam hal ini terdapat kegiatan Gerakan Desa Tangguh Bencana. Gerakan Desa Tangguh Bencana adalah gerakan yang dilakukan untuk seluruh masyarakat pedesaan dari berbagai elemen baik pemerintah maupun masyarakat dengan cara yang cepat untuk mengangkat kembali nilai-nilai strategis yang diperlukan oleh bangsa dan negara. Nilai-nilai strategis ini dinilai mampu untuk menciptakan kesiagaan dan kenyamanan rakyat sehingga dapat meningkatkan pembangunan kesejahteraan di era globalisasi. Gerakan Desa Tangguh Bencana dapat mengubah cara pandang, pikiran, sikap, dan perilaku yang berorientasi pada maju, dalam menghadapi situasi genting dan darurat terhadap fenomena bencana alam untuk menjadi bangsa yang besar dan mampu berkompetisi dengan bangsa-bangsa lain di dunia.

Berdasarkan pengamatan, penanganan bencana selama ini hanya terfokus pada respon darurat saja. Gerakan bantuan yang dikoordinasi masyarakat awam pun juga lebih terfokus pada penggalangan bantuan untuk kondisi darurat. Padahal penanganan bencana yang menyeluruh meliputi sebelum terjadi bencana, pada saat terjadi bencana, dan setelah terjadi bencana. Penanganan bencana juga bukan hanya 
tanggung jawab pemerintah saja, melainkan harus melibatkan peran masyarakat luas. Inilah yang saat ini dikenal sebagai penanganan bencana berbasis masyarakat.

Undang-Undang Nomor 24 Tahun 2007 tentang Penanggulangan Bencana mengamanahkan upaya penanggulangan pada Pasal 35 dan 36 agar setiap daerah dalam upaya penanggulangan bencana dan mempunyai perencanaan penanggulangan bencana. Dibutuhkan dukungan dari berbagai aspek untuk mewujudkan upaya penanggulangan bencana menjadi suatu pedoman nyata dan dipahami oleh masyarakat pada suatu daerah. Partisipasi masyarakat menjadi salah satu faktor utama untuk melakukan strategi dan manajemen resiko bencana menjadi sesuatu yang dilakukan bersama dan menjadi tanggung jawab bersama.

Pandangan dan maksud penelitian yang dilakukan oleh tim penulis yang juga menjadi bagian dari mahasiswa Perguruan Tinggi sangat relevan dan berkaitan erat dengan Tri Dharma Perguruan Tinggi yang diatur dan sesuai dengan Undang-Undang Republik Indonesia Nomor 12 Tahun 2012 Bab 11 yaitu Pengabdian Masyarakat menurut Pasal 47 Ayat 2. Pada bagian ini, pengabdian pada masyarakat dapat dilakukan dalam berbagai bentuk kegiatan sesuai dengan budaya akademik, keahlian, dan/atau otonomi keilmuan civitas akademika serta kondisi sosial budaya masyarakat. Program pengabdian pada masyarakat merupakan salah satu program yang dilaksanakan, baik oleh dosen/tenaga pengajar maupun oleh mahasiswa dengan berlandaskan pada prinsip-prinsip, kompetensi akademik, dan professional di bidangnya sehingga dapat menghasilkan program pengabdian pada masyarakat yang bermutu, relevan, dan sinergi dalam meningkatkan pemberdayaan masyarakat, dalam hal ini dengan memberikan dan membantu masyarakat dengan memberikan semacam pelatihan pemberdayaan dengan melibatkan masyarakat setempat mengenai pembentukan dan pendampingan Desa Tangguh Bencana dengan fokus penanggulangan bencana alam yang terjadi di Desa Ngargoyoso, Kecamatan Ngargoyoso, Kabupaten Karanganyar, Jawa Tengah.

\section{METODE PENELITIAN}

Penelitian dilakukan di Desa Ngargoyoso Kecamatan Ngargoyoso Kabupaten Karanganyar. Secara administratif, Desa Ngargoyoso terdiri dari 6 Dusun, 13 Rukun Warga dan 30 Rukun Tetangga.

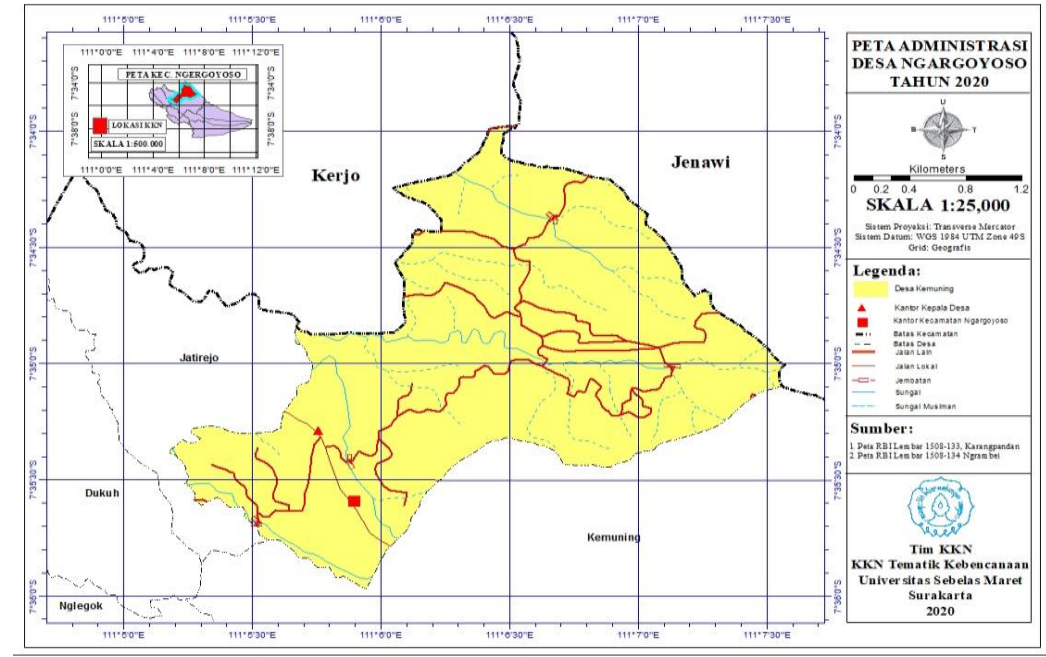

Gambar 1. Peta Lokasi Penelitian

Penelitian ini merupakan jenis penelitian kualitatif deskriptif dalam natural setting karena penelitian ini tidak memanipulasi latar belakang penelitian. Data untuk mengetahui status Desa Tangguh Bencana (DESTANA) diperoleh dengan 
memberikan angket yang diisi oleh perangkat desa. Kuisioner tersebut berasal dari panduan Badan Nasional Penanggulangan Bencana (BNPB). Data yang diperoleh diolah dengan sistem skoring. Setiap jawaban "Ya" memperoleh skor "1", sedangkan setiap jawaban "Tidak" memperoleh skor "0". Klasifikasi DESTANA sebagai berikut:

\begin{tabular}{|c|c|}
\hline Desa/Kelurahan Tangguh Bencana Utama & $>83,33$ \\
\hline Desa/Kelurahan Tangguh Bencana Madya & $58,33-83,33$ \\
\hline Desa/Kelurahan Tangguh Bencana Pratama & $<58,33$ \\
\hline
\end{tabular}

Gambar 2. Klasifikasi DESTANA

Sumber: BNPB

Penelitian ini juga mengukur tingkat ketangguhan keluarga dan individu terhadap wabah Covid-19. Metode pengambilan sampel yang dilakukan pada penelitian ini adalah Random sampling terhadap kepala keluarga masyarakat setempat. Untuk menentukan jumlah responden masyarakat, dapat menggunakan Rumus Slovin (Arikunto, 2006):

$$
\begin{aligned}
& \mathrm{n}=\frac{\mathrm{N}}{\mathrm{N}\left(\mathrm{e}^{2}\right)+1} \\
& \text { Keterangan: } \\
& \mathrm{n}=\text { Jumlah responden (masyarakat) } \\
& \mathrm{N}=\text { Jumlah total kepala keluarga }(\mathrm{KK}) \text { yang menggunakan mataair di } \\
& \text { Kecamatan Donorojo } \\
& \mathrm{e}=\text { Margin/ batas eror (15\% untuk }>100 \text { populasi) }
\end{aligned}
$$

Data yang diperoleh diolah dengan sistem skoring. Setiap jawaban "Ya" memperoleh skor "1", sedangkan setiap jawaban "Tidak" memperoleh skor "0". Klasifikasi Keluarga Tangguh Bencana sebagai berikut:

Tabel 1. Klasifikasi Keluarga Tangguh Bencana

\begin{tabular}{|l|c|}
\hline \multicolumn{1}{|c|}{ Klasifikasi } & Skor \\
\hline Keluarga Tangguh Bencana Rendah & $0-7$ \\
\hline Keluarga Tangguh Bencana Sedang & $8-15$ \\
\hline Keluarga Tangguh Bencana Tinggi & $>15$ \\
\hline
\end{tabular}

Penelitian ini menggunakan penelitian deskriptif kualitatif adalah penelitian yang diuraikan dengan kata-kata menurut pendapat responden apa adanya sesuai jawaban responden dan mencoba untuk mendapatkan pemahaman dari proses dan interaksi.

\section{A. Lokasi Sebaran Area Longsor}

\section{HASIL DAN PEMBAHASAN}

Dua dusun di Desa Ngargoyoso, Kecamatan Ngargoyoso, Kabupaten Karanganyar yaitu Dusun Melikan dan Dusun Tlobo merupakan daerah yang sangat rawan terjadi longsor. Hal tersebut disebabkan karena dusun tersebut berada di lereng Gunung Lawu yang mempunyai kemiringan sedang hingga terjal. Sehingga bila di musim penghujan atau jika di guyur hujan deras akan sangat memungkinkan terjadi bencana tanah longsor di kedua dusun tersebut. Selain disebabkan oleh kondisi daerah yang berada di lereng yang terjal, tanah longsor juga sangat 
memungkinkan disebabkan oleh tikus yang membuat lubang sembarangan di tanah daerah tersebut. Jumlah tikus yang diperkirakan mencapai ratusan dan membuat lubang secara acak dan sembarangan dinilai semakin menambah kondisi rawan daerah tersebut. Selain akrena faktor lubang tikus, kondisi lokasi geografis daerah tersebut merupakan daerah dengan topografi yang curam. Kemiringan lereng di dua dusun tersebut agak curam hingga curam. Dampak bencana alam khususnya tanah longsor dapat dikurangi dengan menurunkan kerawanan bencana, membuat suatu prakira bencana melalui pediksi cuaca sebelum kejadian sangat membantu dalam penanganan bencana alam (Bell, 2002).

B. Karakter Desa Ngargoyoso

Dari data yang diperoleh, terdapat 112 pertanyaan diperoleh skor diketahui klasifikasi Desa Ngargoyoso termasuk dalam desa tangguh madya.

Diketahui pula dari 5 komponen destana, di Desa Ngargoyoso memiliki kualitas dan layanan dasar yang sangat baik, sedangkan yang sangat kurang pada pengelolaan risiko bencana.

\begin{tabular}{|c|c|c|c|c|}
\hline NO. & KOMPONEN & $\begin{array}{c}\text { INDEKS } \\
\text { KOMPONEN }\end{array}$ & $\begin{array}{l}\text { INDEKS DESA } \\
\text { TANGGUH }\end{array}$ & $\begin{array}{c}\text { TINGKAT } \\
\text { KETANGGUHAN } \\
\text { DESA }\end{array}$ \\
\hline 1 & Kualitas dan Akses Layanan Dasar & 0.94 & \multirow{5}{*}{70.15} & \multirow{5}{*}{$\begin{array}{l}\text { TANGGUH } \\
\text { MADYA }\end{array}$} \\
\hline 2 & Dasar Sistem Penanggulangan Bencana & 0.64 & & \\
\hline 3 & Pengelolaan Risiko Bencana & 0.36 & & \\
\hline 4 & Kesiapsiagaan darurat & 0.83 & & \\
\hline 5 & Kesiapsiagaan Pemulihan & 0.52 & & \\
\hline
\end{tabular}

Gambar 3. Komponen DESTANA Desa Ngargoyoso
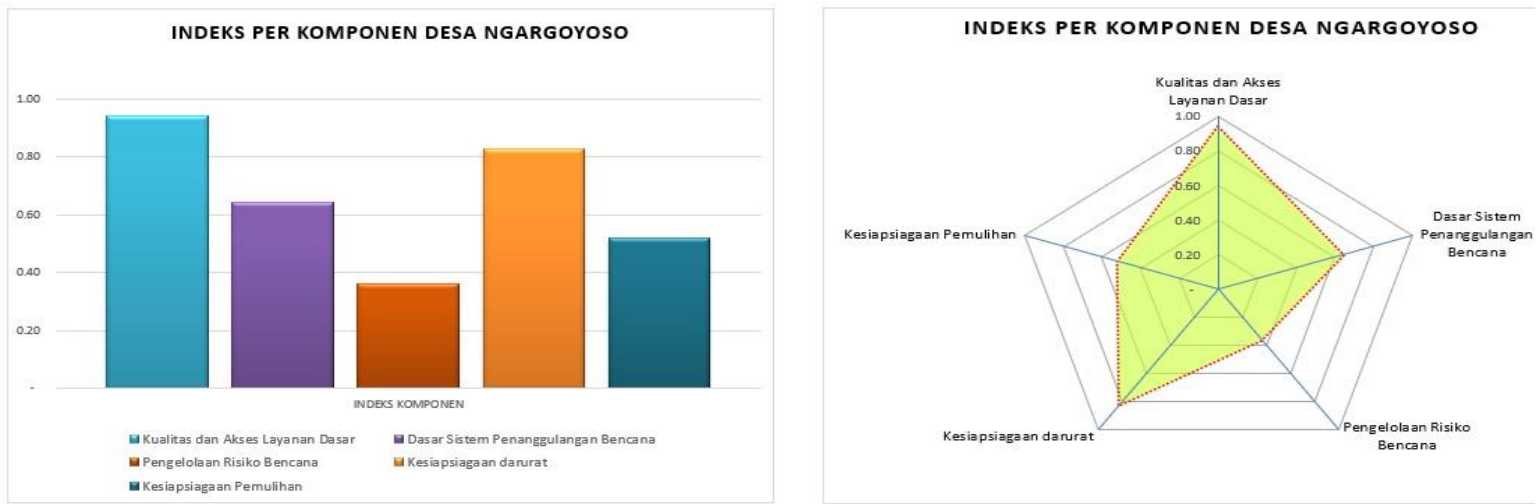

Gambar 4. Indeks Per Komponen Desa Ngargoyoso

Kualitas dan akses layanan dasar memperoleh skor 0.94 dari indikator berupa kualitas pelayanan insfrastruktur dan aset produktif masyarakat; kualitas pelayanan publik dan tata kelola pemerintah desa; dan kualitas layanan lingkungan, budaya dan kemanan. Kemudian dasar sistem penanggulangan bencana memperoleh skor 0,64 dari indikator berupa Regulasi; KRB; RPB; Forum. Kemudian pengelolaan risiko bencana memperoleh skor 0,36 dari indikator Aksi; Edukasi dan sosialisasi. Kemudian kesiapsiagaan memperoleh skor 0,83 dari indikator Peringatan dini; Relawan. Dan terakhir kesiapsiagaan pemulihan mendapat skor 0,52 dari indikator Pemulihan Dini; dan Pemulihan berkelanjutan. 


\section{Penyebab terjadinya tanah longsor}

\section{Kondisi geografis}

Kondisi geografis di Desa Ngargoyoso terutama di dua dusun yaitu Dusun Melikan dan Dusun Tlobo yang berada di kaki lereng Gunung Lawu dengan kemiringan agak curam hingga sangat curam menjadi penyebab utama terjadinya tanah longsor di daerah tersebut. Berikut indokator kemiringan lereng yang digunakan:

Tabel 2. Kelas Kemiringan Lereng

\begin{tabular}{|c|c|c|c|}
\hline Kelas & Kemiringan (\%) & Klasifikasi & Nilai skor \\
\hline I & $0-8$ & Datar & 20 \\
II & $8-15$ & Landai & 40 \\
III & $15-25$ & Agak Curam & 60 \\
IV & $25-45$ & Curam & 80 \\
V & $>45$ & Sangat & 100 \\
\hline
\end{tabular}

Kondisi geografis lainnya berupa tanah yang ada di Desa Ngargoyoso. Parameter sifat fisik tanah merupakan salah saru faktor penting pemicu terjadinya tanah longsor. Faktor sifat fisik tanah yang dimaksud antara lain tekstur, permeabilitas dan juga kedalaman efektif tanah. Data sifat fisik tanah diatas didapatkan dari pengamatan lapang dan analisis laboratorium pada tiap satuan peta lahan yang sudah dibuat. Peristiwa longsor erat kaitannya dengan tinggi rendahnya tingkat permeabilitas tanah yang dinyatakan dengan konduktivitas hidraulik jenuh. Pada kondisi tanah yang jenuh semua pori terisi air dan mengalirkan air sehingga kontinuitas serta kehantaran dalam keadaan maksimum. Apabila dominasi tanah cenderung memiliki populasi pori-pori tanah yang relatif kecil maka kemampuan tanah dalam mengalirkan air sangat sedikit sehingga lapisan atas sampai batas kontak lapisan kedap air akan terus menerus terisi air dan tidak mampu mengalir kelapisan lebih bawah. Oleh karena itu terjadi penjenuhan dan berpotensi longsor (Prijono et al., 2009)

2. Lubang tikus tanah

Keberadaan tikus tanah yang berjumlah ratusan hingga ribuan dan membuat lubang di tanah secara sembarangan merupakan salah satu faktor penyebab terjadinya tanah longsor di desa tersebut. Hal ini disebabkan lubang bekas galian tikus tanah tersebut yang di aliri oleh air akan menggemburkan tanah dan membuat kekokohan tanah berkurang sehingga dapat menyebabkan terjadinya tanah longsor.

\section{KESIMPULAN}

\section{SIMPULAN}

Berdasarkan penelitian yang sudah dilakukan terkait "Pembentukan dan Pendampingan Desa Tangguh Bencana Di Desa Ngargoyoso, Kecamatan Ngargoyoso, Kabupaten Karanganyar" diperoleh kesimpulan sebagai berikut:

$>$ Dari 5 komponen penilaian ketangguhan bencana desa yaitu kualitas dan akses layanan dasar, dasar sistem penanggulangan bencana, pengelolaan risiko bencana, kesiapsiagaan darurat, kesiapsiagaan pemulihan di dapat 
indeks komponen kualitas dan akses layanan dasar Desa Ngargoyoso sangat baik sebesar 0,94 . Sedangkan yang masih sangat kurang pada komponen pengelolaan risiko bencana dengan indeks komponen 0,36. Tingkat ketangguhan Desa Ngargoyoso termasuk dalam kategori Desa Tangguh Madya dengan dengan diperoleh indeks desa tangguh sebesar 70,15.

$>$ Sikap manusia merupakan salah satu faktor penentu perilaku, karena sikap berhubungan dengan persepsi, kepribadian, dan motivasi. Sikap diartikan sebagai kesiapsiagaan mental, yang dipelajari dan diorganisasi melalui pengalaman, dan mempunyai pengaruh tertentu atas tanggap seseorang terhadap orang lain, objek, dan situasi yang berhubungan dengannya (Gibson, 1998). Dalam hal ini, penyikapan dari warga Desa Ngargoyoso, Kecamatan Ngargoyoso, Kabupaten Karanganyar, Jawa Tengah terhadap Penanggulangan Risiko Bencana (PRB) belum memiliki kesadaran penuh dan cara menyikapi obyek dan situasi yang berhubungan kehidupan sehari-hari di desa Ngargoyoso belum dipersiapkan secara mental dan pengalaman serta belum adanya pengaruh dari berbagai ahli atau relawan yang cukup pengetahuannya.

\section{SARAN}

Untuk mewujudkan desa tangguh bencana serta memperkuat pengelolaan risiko bencana maka rekomendasi aksi yang dapat diberikan berdasarkan penelitian ini adalah:

> Untuk memperkuat dasar sistem penanggulangan bencana, bentuk forum PRB dengan melibatkan setiap pemangku kepentingan yang dikuatkan dengan Perdes/SK Kades/SK Lurah

$>$ Untuk memperkuat pengelolaan risiko bencana, perlu identifikasi potensi kerugian pada semua jenis bencana, tuangkan dalam dokumen RPBDes dan identifikasi pengetahuan/ketrampilan kebencanaan hasil pelatihan

$>$ Untuk memperkuat keiapsiagaan darurat, bentuk organisasi relawan, perkuat dengan legalitas (Perdes/SK), berikan fasilitas peralatan, dan laksanakan latihan berkala dalam kegiatan di setiap tahapan penaggulangan bencana

\section{DAFTAR PUSTAKA}

Bell, F.G. 2002. Geological Hazard. Their Assessment, Avoidance and Mitigation. Taylor and Francis E-library. USA and Canada

Gibson (1998). Pengelolaan Bencana Terpadu: Banjir, Longsor, Kekeringan dan Tsunami. Yusuf Watampone Press. Jakarta.

Sunaryo. (2004). Disaster Manajemen di Negeri Rawan Bencana. Cetakan Pertama, PT Aksara Grafika Pratama, Jakarta

Indonesia. Undang-Undang RI No.24 Tahun 2007 Tentang Penanggulangan Bencana: Jakarta; 2007

Badan Nasional Penanggulangan Bencana. Peraturan Kepala Badan Nasional Penanggulangan Bencana Nomor 4 Tahun 2008 Tentang Pedoman Penyusunan Rencana Penanggulangan Bencana. Jakarta. 2008

Badan Nasional Penanggulangan Bencana. Rencana Nasional Penanganan Bencana 2010- 2014. Jakarta; 2009.

Badan Nasional Penanggulangan Bencana. Peraturan Kepala BNPB Nomor 1 Tahun 2012 tentang Pedoman Umum Desa/Kelurahan Tangguh Bencana. BNPB: Jakarta; 2012.

Badan Nasional Penanggulangan Bencana. Pedoman Sistem Peringatan Dini Berbasis Masyarakat. 2012 
SHEs: Conference Series 3 (1) (2020) $299-306$

Indonesia. Undang-Undang Republik Indonesia Nomor 12 Tahun 2012 Tentang Perguruan Tinggi: Jakarta; 2012.

Pusat Data Informasi dan Hubungan Masyarakat Badan Nasional Penanggulangan Bencana. Buku Saku Tanggap Tangkas Tangguh. Maret 2019. 